\title{
The Impact of Youth Unemployment Due To Work Experience Required by Business Houses, Lusaka Zambia
}

\author{
Ananda Kumar Aroumougame 1*, Jackson Sishumba ${ }^{2}$, Nick Pimpa Chisumpa ${ }^{3}$ \\ ${ }^{1-3}$ Department of Management and Commerce, DMI - ST. EUGENE UNIVERSITY, Lusaka, Zambia \\ *Corresponding Author E-mail: searchanandu@gmail.com
}

\begin{abstract}
Research papers looking deep into the causes of youth unemployment focus not only on the causes but solutions of the unemployment rate in Lusaka Zambia. The government of Zambia recognizes these challenges and has pledged to increase employment in general, and employment for youth in particular. So far, however, his initiative has not made the needed difference. Often in business life young people are not given the opportunity or opportunity to express their abilities in relation to the skills they have acquired while in college. This study uses quantitavie method. Result The Government of the Republic of Zambia has in many cases talked ab out reducing the unemployment rate but the question is what has been done about it? More local flexibility in the design and implementation of policies to address youth unemployment could solve this problem. Participation in work operations results in gains in employment as income in the post-program period and decreases in welfare and unemployment receipts and payments. This positive effect persistsat a relatively stable level for up to four years after youth leave the program.
\end{abstract}

Keywords: Jobs, Unemployment, Young People, Youth.

\begin{abstract}
Abstrak
Makalah penelitian melihat jauh ke dalam penyebab pengangguran kaum muda tidak hanya fokus pada penyebab tetapi solusi dari tingkat pengangguran di Lusaka Zambia. Pemerintah Zambia menyadari tantangan tersebut dan telah berjanji untuk meningkatkan lapangan kerja secara umum, dan lapangan kerja bagi kaum muda pada khususnya. Sejauh ini, bagaimanapun, inisiatifnya belum membuat perbedaan yang dibutuhkan. Sering kali dalam kehidupan bisnis kaum muda tidak diberi kesempatan atau kesempatan untuk mengekspresikan kemampuan mereka sehubungan dengan keterampilan yang mereka peroleh selama di bangku kuliah. Penelitian ini menggunakan metode kuantitatif. Menghasilkan Pemerintah Republik Zambia dalam banyak kasus telah berbicara tentang pengurangan tingkat pengangguran tetapi pertanyaannya adalah apayang telah dilakukan untuk itu? Lebih banyak fleksibilitas lokal dalam desain dan implementasi kebijakan untuk mengatasi penganggu ran muda dapat memecahkan masalah ini. Partisipasi operasi kerja menghasilkan keuntungan dalam pekerjaan sebagai pendapatan pada periode pasca program dan penurunan penerimaan dan pembayaran kesejahteraan dan pengangguran. Efek positif ini bertahan pada tingkat yang relatif stabil hingga empat tahun setelah pemuda meninggalkan program.
\end{abstract}

Kata Kunci: Pekerjaan, Pengangguran, Pemuda, Pemuda.

\section{INTRODUCTION}

According to the Bhoratet al (2015), definesyouth as a person between the ages of 15 and 29; the United Nations (UN) defines youth as people between the ages of 14 and 25, while the National Youth Development Council (NYDC) defines youth as all young people between the ages of 12 and 35. Youth unemploymentis defined by the International Labour Organization(ILO) as the unemployed youth labor force. All persons over a certain age who were unemployed, currently available for employment, and

\section{* Copyright (c) 2021 Ananda Kumar et.al}

This work is licensed under a Creative Commons Attribution-ShareAlike 4.0 International License

Received: January 3, 2021 ; In Revised : January 25, 2021; Accepted : July 6, 2021 
Khazanah Sosial, Vol. 3 No. 3:118-129

The Impact of Youth Unemployment Due To Work Experience Required by Business Houses, Lusaka Zambia

Ananda Kumar et.al

actively seeking work at the time of the reference pointare considered unemployed. As a result, the labor force is equal to the total number of working and joblesspeople. In 2007, UN Secretary-General Kofi Annan estimated that there were around 66 million unemployed youngsters in the globe today, up nearly 10 million since 1965 (Lim, 2013).

Dr. Rupiah Bwezani Banda, Zambia's former president, recommended in October 2011 that the country'snormal retirement age be raised from 55 to 65 years, This has sparked policydebate among the country's many stakeholders. This proposal could have come from the idea that most people reach the conventional retirement age at a point in their life when they are still ready and able to work actively (Kabelenga, 2017; Sanches, 2016). This can be seen in the rising number of retired people returning to contract work that they held prior to retirement. The increased life expectancy has undoubtedly further motivated this argument as one of the most encouraging developments for least developed countries in the recent few decades.

Youth unemployment is one of the most serious issues confronting Zambian youth today (Ajufo, 2013; Chigunta \& Mwanza, 2016). There are a large number of young people with strong qualifications who are unemployed. They simply cannot find work. It hurts them every time they arein charge of a family or caring for their brothers and sisters (Mungule, 2016). Youths struggle to find employment as a result of those that have attained the retirement age continue to hold position in most of these government institutions and the business houses making it almost impossible for youths to have employment opportunities. For some time now, the youths all over Zambia have been facing challenges of finding employment in companiessoon after they graduate without hand-on experience. This will be a challenge in carrying out their duties as they only have the knowledge in theory and not practical. The Zambian former minister of information, broadcasting and labour, fackson shamenda, concurred, "There isa lack of co-ordination in our efforts to address the issue of youth unemployment. We need to find appropriate mechanism to better co-ordinate our programs if we are to achieve our goals." These words were powerful but nothing much was done about itover job creation.

Guarcello et al (2008) examined variousaspects of unemployment in torpor, as well as the impact of a few key variables on employment growth. He ascribed the unemployment problem to reasons such as selectivity among school graduates, who expect/aspire to work in the modern economy despite the sector's limited chances.. Chigunta and Mwanza (2016) focused on the characteristics of juvenile labor markets and young people as a whole, as well as the behavioral and personal traits of individuals that influence their ability to find job. Micklewright (1999) Because training is expensive, most employees prefer ready-made resources, such as those tutored in work ethics. Gough, Chigunta and Langevang (2016) claim that young people who are unable to find work wind up in slums and on thestreets, where they indulge in unproductive activities such as prostitution, drugusage, and substance abuse. During this moment of transition, many young people face considerable hardships.Chigunta (2017) According to the author, the consequences of teenage unemployment include poverty, homelessness, and housing issues, increased crime rates in some places, a lack of youth participation in society, and low morale among young people. differentfrom other studies, this study looks further into the problem of unemploymentfrom the zambia government's policy on increasing the retirement age which is a deficiency in research on unemployment in Zambia. The overall goal of this study was to look into the impact on youth who are consistently denied employment opportunities by the business world due to a lack of experience in a particular field after successfully completing several years of study, as well as the impact of Zambian youth adjusting to a retirement age of 55-65 years. 
Youth if given the opportunity in most businesses, they will play an important role in decision making and the growth and development of Zambia's economy (Lindsey \& Grattan, 2012). Youth will continue to be essential to any economic growth. Youth is the package of any state. Therefore, it is necessary to determine work experience and also look at the effect of retirement age. Therefore, this research was conducted in Lusaka District which is the main business center due to limited resourcesand time and dueto the issues circulating around covid-19.

\section{RESEARCHMETHOD}

\section{General Objective}

The study investigates the impact of youth unemploymentand its force to the Zambian economy.

\section{Specific Objectives}

These are the following objectives that the researcher would like to achieve

1. To analyse the impact of retirement age and work experience required by business houses to youth employment.

2. To find out the specific system to be employed by both government and the business houses to ensure that qualified youths aregiven an equal opportunity.

3. To establish the role on offeringretired personnel contractual jobs.

4. To source for the reasons asto why the required experience by business houses.

5. To understand the basic requirement of entry in any businesshouse

\section{Method}

In a systematic approach, research design refers to the precise nature of research effort. Itincludes details regarding the research project, including the study's framework, data availability, observations, analysis, and sampling. The research method used in this project was descriptive and quantitative in character. Descriptive research is simply fact-finding that is primarily concerned with the present, abstractinggenerations through a cross-sectional examination of the current situation (Ma, 2006). Simple Random Sample was used as the sampling approach for the study. A simple random sampling is a group of subjectspicked from a bigger group in statistics. Each subject from the population is chosen atrandom and purely by chance, with the same chance of being chosen atany point during the sampling procedure. The study's demographic is confined to youths who are interested in gathering information for the unemployed. The research was carried out in Lusaka, with a few companies and individuals in the city being targeted. Correlation and Chi-square were two of the statistical tests performed in the study. The data was computed and analyzed usingSPSSversion 16.0 (Statistical Package for Social Sciences).

The sample size was 70 people, including 40 teenagers, 15 government officials, 5 parents, 10 directors, and other well-known people in society. The study was to include youths because they were the main perpetrators. Chairpersons were considered and chosen because they were at the vanguard of addressing the effects of adolescent unemployment, as well as solving robbery, substance abuse, and burglary crimes, among other things. Parents were included since they are aware of the majority of the bad activities that their kids and daughters engage in as a result of unemployment. Civil servants were also included since theyare interested in and concerned about community concerns. 
Khazanah Sosial, Vol. 3 No. 3:118-129

The Impact of Youth Unemployment Due To Work Experience Required by Business Houses, Lusaka Zambia

Ananda Kumar et.al

A questionnaire was used to obtain primary data. A pre-test was completed before the questionnaire was given to the people, and twentyyoung people were picked for the purpose. The survey was based on the fact that many young people are unemployed. A self-administered, non-disguised fivepoint scale questionnaire with 41 statements was utilized for primary data collection. The measure was a five-point Likert scale, with respondents having to select one option from strongly agree to strongly disagree. The data wasto be collected over a three-month period from 50 persons, including youths and working people. Secondary data was gathered from a variety of sources, including the Internet, books, newspapers, journals, and business publications.

\section{RELIABILITYTEST}

Reliability means the ability of a measuring instrument to give accurate and consistent results (Mohajan,2017). Only the questions used to test perception that cannot be adequately measured raise the issue of dependability. In this study, statements are utilized to examine the impact of adolescent unemploymentas a result of corporate houses' demand for job experience. A five-point scale isutilized for all of the statements.

A modest pilot research is conducted before the full-fledged data collecting begins to ensure that the constructs contained in the questionnaire are reliable. This will ensure that the constructs included in the questionnaire capture all of the data required for the study. The questionnaire was further updated based on the results of the pilot study to ensure that it would best serve the purpose of obtaining the needed information about the Impact of Youth Unemployment Due to Work Experience Required by Business Houses. The full-scale survey will be conducted using this final questionnaire.

The Cronbach alpha is determined using SPSS 16 to determine the instrument's reliability. If the alpha value is more than 0.5 , the instrument is considered dependable. Initially, the data was used to determine the al pha value. This survey was done not only to assess the instrument's reliability, but also to make necessary changes to the questionnaire in order to extract the information needed from respondents. Table 1 shows the measured dependability levelsat various phases.

Table 1. Cronbach's Alpha Test for Reliability

\begin{tabular}{ccc}
\hline Reliability Statistics & & \\
\hline Cronbach's Alpha & $\begin{array}{c}\text { Cronbach's Alpha Based on } \\
\text { Standardized Items }\end{array}$ & No. of Items \\
\hline .841 & .840 & 40 \\
\hline
\end{tabular}

The Cronbach's alpha value is clearly shown in table 1 . Cronback's alpha values must be greater than 0.05 to meet the standard criterion.Cronbach's alpha values for data obtained from 70 respondents with 40 statements after making changes are more than 0.841 average Cronbach's alpha value, which means the items or statements used to assess the dimensions or reliable variables are more than 0.841 average Cronbach's alpha value. This means that no changes to the study instrument are required, and there is no early response bias. The statementsused to quantify theimpact of adolescent unemployment due to work experience requirements by businessesare shown in this reliability test. Asa result, it may be deduced that each statement is useful in gauging public opinion in the studied area. These statements can be used to calculate the variation of individual traits. The research tool is now completely ready for a largescale survey. 


\section{RESULT AND DISCUSSION}

\section{Result}

\section{Factor Analysis of Impact of Youth Unemployment Due to Work Experience Required By Business Houses}

The following tables discuss the results relating to measure of impact of youth unemployment due to work experience required by business houses on the basis of factor analysis. The basic objectives of factor analysis are to reduce the data related to the variables under the study to a manageable form with retaining as much information as possible. Principal Component Analysis (PCA) method was used infactor analysis has been described table 2 .

Table 2. Kaiser-Meyer-Olkin Measure of Sample Adequacy

\begin{tabular}{lcc}
\hline \multicolumn{3}{c}{ KMO and Bartlett's Test } \\
\hline \multicolumn{3}{c}{ Kaiser-Meyer-Olkin Measure of Sampling Adequacy. } \\
\hline \multirow{3}{*}{ Bartlett's Test of Sphericity } & Approx. Chi-Square & $\mathbf{0 . 6 7 2}$ \\
\cline { 2 - 3 } & Df & 2206.784 \\
\cline { 2 - 3 } & Sig. & 780 \\
\hline
\end{tabular}

Source: Processed by researchers 2020

Table 2 shows the suitability of data for factor analysis. The value of Kaiser- Meyer-Olkin (KMO) Measure of Sample Adequacy is $\mathbf{0 . 6 7 2}$ which is considered "superb" (Hutcheson \& Sofroniou, 1999), showing that sample size is adequate for our study. Based on significance value, Barlett"s Test of Sphericity also shows the suitability of data for factor analysis (Pallant, 2001). Impact of youth unemployment due to work experience required by business houses variables is consisting of 40 statements. It is very difficult to analyze the interpretation of those statements due to large number of statements. In order to reduce those statements, we have been used factor analysis. It will separate those statements into similar or same group statements.

The Kaiser-Meyer-Olkin meaure of sampling adequacy and Bartlett"stestsphericity is used to test the sample adequacy for applying factor analysis. Kaiser recommends values greater than 0.5 as acceptable. Since the value is 0.672 , it is a good value and hence we are confident that factor analysis could be appropriate for these data. The Bartlett"s test of sphericity is significant, hence the $\mathrm{R}$ - matrix is not an identity matrix. It reveals that there is some relationship between variables and therefore the factor analysis is appropriate for these data.

Before going for factor analysis, suitability of data for the purpose of factor analysishasto be tested KMO test and Bartlett"s test is two such tests. The value of KMO of 0.672 indicatesthat a factor analysisis useful for the present data. Bartlett"s test of Sphericity indicates whether the correlation matrix is an identity matrix, which would indicate that the variables are unrelated. The significance level gives the result of the test. Here, the significant value is 0.000 which indicates that there exists significant relationship among the variables. The resultant value of KMO test and Bartlett"s test indicate that the present data is useful for factor analysis. 
Khazanah Sosial, Vol. 3 No. 3:118-129

The Impact of Youth Unemployment Due To Work Experience Required by Business Houses, Lusaka Zambia

Ananda Kumar et.al

Table 3. Extracted Factor of Effectiveness of Impact of Youth Unemployment Due to Work Experience Required by Business Houses Reliabilities

\begin{tabular}{|c|c|c|c|c|c|c|}
\hline \multicolumn{7}{|c|}{$\begin{array}{r}\text { Total Variance Explained } \\
\end{array}$} \\
\hline \multirow{2}{*}{ Component } & \multicolumn{3}{|c|}{ Initial Eigenvalues } & \multicolumn{3}{|c|}{ Extraction Sums of Squared Loadings } \\
\hline & Total & $\%$ of Variance & Cumulative \% & Total & $\%$ of Variance & Cumulative $\%$ \\
\hline 1 & 7.819 & 19.547 & 19.547 & 7.819 & 19.547 & 19.547 \\
\hline 2 & 3.722 & 9.306 & 28.852 & 3.722 & 9.306 & 28.852 \\
\hline 3 & 3.022 & 7.555 & 36.408 & 3.022 & 7.555 & 36.408 \\
\hline 4 & 2.748 & 6.869 & 43.277 & 2.748 & 6.869 & 43.277 \\
\hline 5 & 2.343 & 5.856 & 49.133 & 2.343 & 5.856 & 49.133 \\
\hline 6 & 2.079 & 5.198 & 54.331 & 2.079 & 5.198 & 54.331 \\
\hline 7 & 1.892 & 4.730 & 59.062 & 1.892 & 4.730 & 59.062 \\
\hline 8 & 1.669 & 4.173 & 63.235 & 1.669 & 4.173 & 63.235 \\
\hline 9 & 1.518 & 3.795 & 67.030 & 1.518 & 3.795 & 67.030 \\
\hline 10 & 1.397 & 3.491 & 70.521 & 1.397 & 3.491 & 70.521 \\
\hline 11 & 1.317 & 3.291 & 73.812 & 1.317 & 3.291 & 73.812 \\
\hline 12 & 1.077 & 2.692 & 76.504 & 1.077 & 2.692 & 76.504 \\
\hline 13 & 1.042 & 2.605 & 79.109 & 1.042 & 2.605 & 79.109 \\
\hline 14 & .919 & 2.298 & 81.407 & & & \\
\hline 15 & .876 & 2.191 & 83.599 & & & \\
\hline 16 & .747 & 1.869 & 85.467 & & & \\
\hline 17 & .697 & 1.743 & 87.210 & & & \\
\hline 18 & .642 & 1.606 & 88.816 & & & \\
\hline 19 & .548 & 1.369 & 90.185 & & & \\
\hline 20 & .527 & 1.316 & 91.502 & & & \\
\hline 21 & .477 & 1.192 & 92.694 & & & \\
\hline 22 & .394 & .984 & 93.678 & & & \\
\hline 23 & .376 & .941 & 94.619 & & & \\
\hline 24 & .336 & .840 & 95.459 & & & \\
\hline 25 & .312 & .779 & 96.238 & & & \\
\hline 26 & .283 & .708 & 96.946 & & & \\
\hline 27 & .232 & .581 & 97.527 & & & \\
\hline 28 & .207 & .518 & 98.045 & & & \\
\hline 29 & .172 & .431 & 98.475 & & & \\
\hline 30 & .153 & .382 & 98.858 & & & \\
\hline 31 & .122 & .304 & 99.162 & & & \\
\hline 32 & .088 & .220 & 99.382 & & & \\
\hline 33 & .075 & .187 & 99.569 & & & \\
\hline 34 & .042 & .105 & 99.673 & & & \\
\hline 35 & .042 & .104 & 99.777 & & & \\
\hline 36 & .033 & .082 & 99.859 & & & \\
\hline 37 & .023 & .058 & 99.917 & & & \\
\hline 38 & .013 & .032 & 99.949 & & & \\
\hline 39 & .011 & .029 & 99.978 & & & \\
\hline 40 & .009 & .022 & 100.000 & & & \\
\hline
\end{tabular}

Source: Processed by researchers 2020

From the 40 statements only 13 statements have Eigen Values more than 1 . This means that these statements can be used to explain maximum variance in the characteristics of people. The total variance accounted by all the cumulative factors scored is 79.107 percent. This means that significant amount of variance is explained by the reduced number of factors in the table 3 .

From the understanding of Figure, the ScreePlot of factor analysis as shown slot with excellent root. Since each of every factor slot are properly divided and denoted. The figure which is classified from the first factor to the last factor. From the rotated component matrix is clearly denoted that each number of factors are allocated the number of statements. These numbers of allocations of statements are automaticallyallocated 13 statements of each factor by the SPSS software. 
Khazanah Sosial, Vol. 3 No. 3 : 118-29

The Impact of Youth Unemployment Due To Work Experience Required by Business Houses, Lusaka Zambia

Ananda Kumar et.al

Table 3 reveals that 40 statements are divided into 13 factors. Each factor has Initial Eigenvalues. The first factor of initial eigenvalues are scored 7.819 percent, the $2^{\text {nd }}$ factor of initial eigenvalues are scored 3.722, the $3^{\text {rd }}$ factor of initial eigenvalues are scored 3.022, the $4^{\text {th }}$ factor of initial eigenvalues are scored 2.748 , the $5^{\text {th }}$ factor of initial eigenvalues are scored 2.343 , the $6^{\text {th }}$ factor of initial eigenvalues are scored 2.079 , the $7^{\text {th }}$ factor of initial eigenvalues are scored 1.892 , the $8^{\text {th }}$ factor of initial eigenvalues are scored 1.669, the $9^{\text {th }}$ factor of initial eigenvaluesare scored 1.518 , the $10^{\text {th }}$ factor of initial eigenvalues are scored 1.397 , the $11^{\text {th }}$ factor of initial eigenvalues are scored 1.317 , the $12^{\text {th }}$ factor of initial eigenvalues are scored 1.077, the $13^{\text {th }}$ factor of initial eigenvalues are scored 1.042.

The factor analysis consisted of 13 statements which had the first statement called unemployment, second statement called retirementage, third statement called effects of unemployment, fourth statement called problems of unemployment, fifth statement called government cares, sixth statement called unemployment can be reduced, seventh statement called non job opening, eightieth statement called internship should be given, ninth statement called lack of skills causes youth unemployment, tenth statement called government have jobs for youths, eleventh statement called retirement age is too high, twelfth statement called employees still consider contract basis and thirteenth statement called governmentshould reduce youth unemployment.

\section{Analysis of Inter Correlation Matrix between different Variables}

In order to find out the level of positive or negative correlation between thevariables with the help of inter correlation matrix. The variables such as Unemployment exists in Zambia, Unemployment affects you as a person, Unemployment have an effect on society, Re-recruitment of retired people on contract basis help in fighting unemployment problem, Problems caused by unemployment can be reduced. And also, to understand the level of significant on through the table 4 .

Table 4. Inter-Correlation Matrix And Descriptive Statistics With Year Of Position Held And Other Variables

\begin{tabular}{|c|c|c|c|c|c|c|}
\hline \multicolumn{7}{|c|}{ Correlations } \\
\hline & & $\begin{array}{c}\text { Unemployme } \\
\text { nt exists in } \\
\text { Zambia }\end{array}$ & $\begin{array}{l}\text { Unemployme } \\
\text { nt affects you } \\
\text { as a person }\end{array}$ & $\begin{array}{l}\text { Unemployment } \\
\text { have an effect } \\
\text { on society }\end{array}$ & $\begin{array}{l}\text { Re-recruitment } \\
\text { of retired people } \\
\text { on contract basis } \\
\text { help in fighting } \\
\text { unemployment } \\
\text { problem }\end{array}$ & $\begin{array}{c}\text { Problems } \\
\text { caused by } \\
\text { unemployment } \\
\text { can be reduced }\end{array}$ \\
\hline & Pearson Correlation & 1 & $.603^{* *}$ & $.542^{* *}$ & -.110 & $.378^{* *}$ \\
\hline & $\mathrm{N}$ & 70 & 70 & 70 & 70 & 70 \\
\hline \multirow{3}{*}{$\begin{array}{l}\text { Unemployment } \\
\text { affects you as a } \\
\text { person }\end{array}$} & Pearson Correlation & $.603^{* *}$ & 1 & $.409^{* *}$ & -.015 & $.275^{*}$ \\
\hline & Sig. (2-tailed) & .000 & & .000 & .901 & .021 \\
\hline & $\mathrm{N}$ & 70 & 70 & 70 & 70 & 70 \\
\hline \multirow{2}{*}{$\begin{array}{l}\text { Unemployment have } \\
\text { an effect on society }\end{array}$} & Pearson Correlation & $.542^{* *}$ & $.409^{* *}$ & 1 & .122 & $.437^{* *}$ \\
\hline & Sig. (2-tailed) & .000 & .000 & & .313 & .000 \\
\hline $\begin{array}{c}\text { contract basis help in } \\
\text { fighting } \\
\text { unemployment } \\
\text { problem }\end{array}$ & $\mathrm{N}$ & 70 & 70 & 70 & 70 & 70 \\
\hline \multirow{3}{*}{$\begin{array}{l}\text { Problems caused by } \\
\text { unemployment can } \\
\text { be reduced }\end{array}$} & Pearson Correlation & $.378^{* *}$ & $.275^{*}$ & $.437^{* *}$ & -.152 & 1 \\
\hline & Sig. (2-tailed) & .001 & .021 & .000 & .210 & \\
\hline & $\mathrm{N}$ & 70 & 70 & 70 & 70 & 70 \\
\hline
\end{tabular}

Source: Processed by researchers 2020 
Khazanah Sosial, Vol. 3 No. 3:118-129

The Impact of Youth Unemployment Due To Work Experience Required by Business Houses, Lusaka Zambia

Ananda Kumar et.al

The table 4 reveals that to under the perception through level of positive or negative correlation on through the different variables with the help analysis of inter correlation matrix. Herewith five variables are includes such as Unemployment exists in Zambia, Unemployment affects you as a person, Unemployment have an effect on society, Re-recruitment of retired people on contract basis help in fighting unemployment problem, Problems caused by unemployment can be reduced. The table which shows thatmost positive correlation scored (+.603) Unemployment exists in Zambia and Unemployment affects you as a person. The second most positive correlation scored $(+.542)$ between Unemployment exists in Zambiaand Unemployment havean effect on society.

The most negative correlation scored (-.152) between Re-recruitment of retired people on contract basis help in fighting unemployment problem and Problems caused by unemployment can be reduced. The second most negative scored (-.110) between Unemployment exists in Zambia and Re-recruitment of retired people on contract basis helpin fighting unemployment problem.

\section{Analysis of Inter Correlation Matrix between different Variables}

In order to find outthe level of positive or negative correlation between thevariableswith the help of inter correlation matrix. The variables such as Is reducing unemployment a responsibility of the youth themselves, is reducing unemployment among the youth a responsibility of the state, the church and family play a role in youth unemployment, Government have jobs to offer youths and Can you blame unemployment for theyears required by business houses.

Table 5. Inter-Correlation Matrix And Descriptive Statistics With Year OfPosition Held And Other Variables

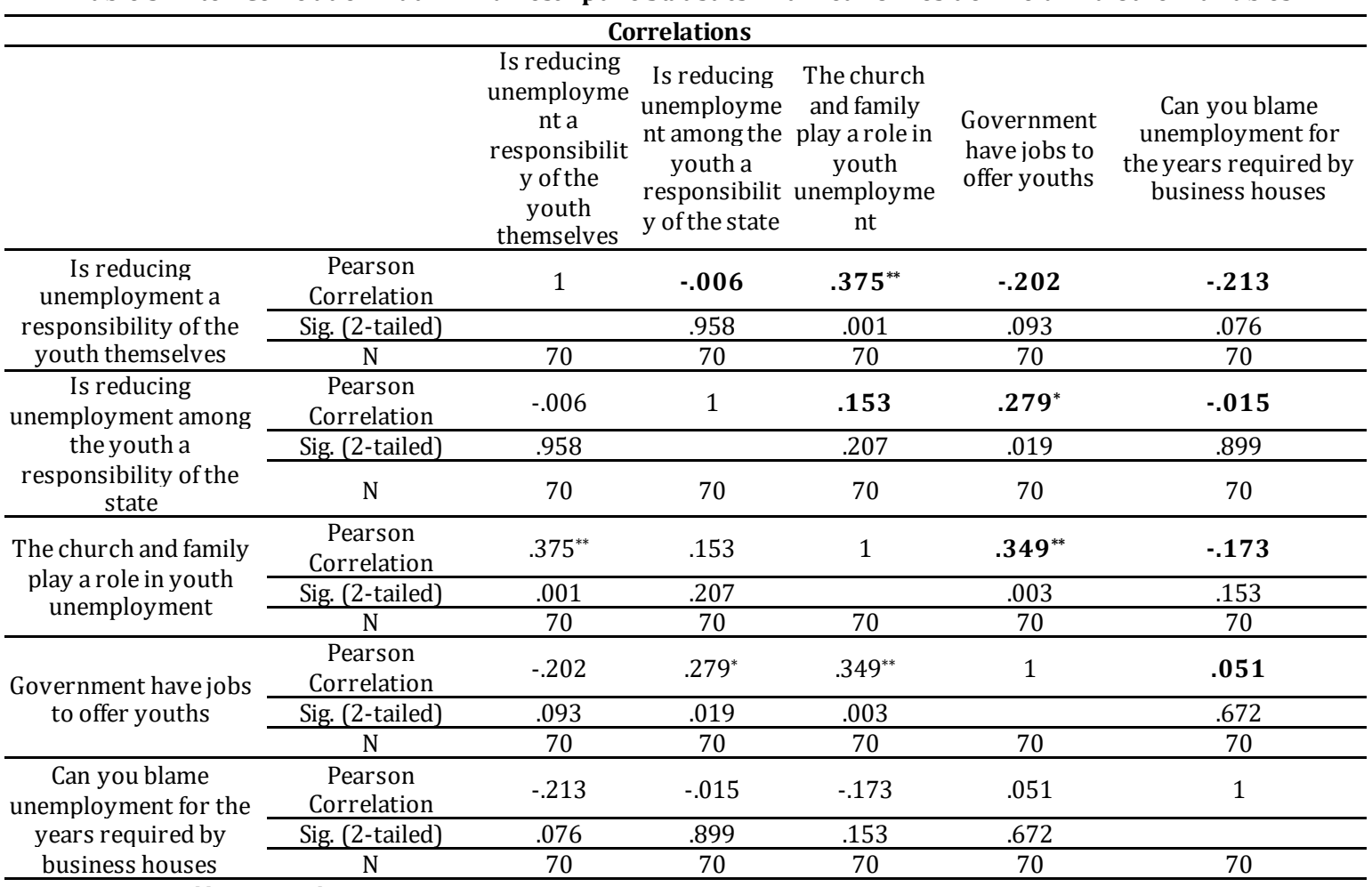

Source: Processed by researchers 2020

The table 5 reveals that to understand the perception through level of positive or negative correlation on through the different variables with the help analysis of inter correlation matrix. Here with five variables are includes such as Is reducing unemployment a responsibility of the youth themselves, is 
Khazanah Sosial, Vol. 3 No. 3 : 118-29

The Impact of Youth Unemployment Due To Work Experience Required by Business Houses, Lusaka Zambia

Ananda Kumar et.al

reducing unemployment among theyouth a responsibility of the state, the church and family playa role in youth unemployment, Government have jobs to offer youths and Can you blame unemployment for the years required by business houses. The table which shows that most positive correlation scored $(+.375)$ between and the church and family play a role in youth unemployment Is reducing unemployment a responsibility of the youth themselves. The second mostpositive correlation scored (+.349) between the church and family playa role in youth unemployment and Government have jobs to offeryouths.

The most negative correlation scored (-.213) between Isreducingunemployment a responsibility of the youth themselves and Can you blame unemploym ent for the years required by business houses. The second most negative scored (-.202) between Is reducing unemployment a responsibility of the youth themselves and Government have jobs to offer youths.

\section{Analysis of Inter Correlation Matrix between different Variables}

In order to find outthe level of positive or negative correlation between thevariables with the help of inter correlation matrix. The variablessuch as the companies employ retired personals Unemployment in Zambia affectthe educated and uneducated in the same way, is it correct to say that most of theyouths in Zambia are unemployed, Government cares over youth unemployment, The society cares over youth unemployment.

Table 6. Inter-Correlation Matrix And Descriptive Statistics With Year Of Position Held And Other Variables

\begin{tabular}{|c|c|c|c|c|c|c|}
\hline \multicolumn{7}{|c|}{ Correlations } \\
\hline & & $\begin{array}{l}\text { The } \\
\text { companies } \\
\text { employ } \\
\text { retired } \\
\text { personals }\end{array}$ & $\begin{array}{c}\text { Unemploy } \\
\text { ment in } \\
\text { Zambia } \\
\text { affect the } \\
\text { educated } \\
\text { and } \\
\text { uneducate } \\
\text { d in the } \\
\text { same way }\end{array}$ & $\begin{array}{c}\text { Is it correct to } \\
\text { say that most } \\
\text { of the youths in } \\
\text { Zambia are } \\
\text { unemployed }\end{array}$ & $\begin{array}{c}\text { Government } \\
\text { cares over } \\
\text { youth } \\
\text { unemployment }\end{array}$ & $\begin{array}{c}\text { The society cares } \\
\text { over youth } \\
\text { unemployment }\end{array}$ \\
\hline \multirow{3}{*}{$\begin{array}{l}\text { The companies employ } \\
\text { retired personals }\end{array}$} & $\begin{array}{c}\text { Pearson } \\
\text { Correlation } \\
\end{array}$ & 1 & -.026 & .074 & .181 & .208 \\
\hline & Sig. (2-tailed) & & .829 & .542 & .133 & .085 \\
\hline & $\mathrm{N}$ & 70 & 70 & 70 & 70 & 70 \\
\hline \multirow{3}{*}{$\begin{array}{c}\text { Unemployment in Zambia } \\
\text { affect the educated and } \\
\text { uneducated in the same } \\
\text { way }\end{array}$} & $\begin{array}{c}\text { Pearson } \\
\text { Correlation }\end{array}$ & -.026 & 1 & $.286^{*}$ & -.091 & .200 \\
\hline & Sig. (2-tailed) & .829 & & .016 & .452 & .097 \\
\hline & $\mathrm{N}$ & 70 & 70 & 70 & 70 & 70 \\
\hline \multirow{3}{*}{$\begin{array}{c}\text { Is it correct to say that most } \\
\text { of the youths in Zambia are } \\
\text { unemployed }\end{array}$} & $\begin{array}{c}\text { Pearson } \\
\text { Correlation } \\
\end{array}$ & .074 & $.286^{*}$ & 1 & $-.412^{* *}$ & .231 \\
\hline & Sig. (2-tailed) & .542 & .016 & & .000 & .054 \\
\hline & $\mathrm{N}$ & 70 & 70 & 70 & 70 & 70 \\
\hline \multirow{3}{*}{$\begin{array}{l}\text { Government cares over } \\
\text { youth unemployment }\end{array}$} & $\begin{array}{c}\text { Pearson } \\
\text { Correlation } \\
\end{array}$ & .181 & -.091 & $-.412^{* *}$ & 1 & $-.469^{* *}$ \\
\hline & Sig. (2-tailed) & .133 & .452 & .000 & & .000 \\
\hline & $\mathrm{N}$ & 70 & 70 & 70 & 70 & 70 \\
\hline \multirow{3}{*}{$\begin{array}{l}\text { The society cares over } \\
\text { youth unemployment }\end{array}$} & $\begin{array}{c}\text { Pearson } \\
\text { Correlation } \\
\end{array}$ & .208 & .200 & .231 & $-.469^{* *}$ & 1 \\
\hline & Sig. (2-tailed) & .085 & .097 & .054 & .000 & \\
\hline & $\mathrm{N}$ & 70 & 70 & 70 & 70 & 70 \\
\hline
\end{tabular}

Source: Processed by researchers 2020

The table 6 reveals that to under the perception through level of positive or negative correlation on through the different variableswith the help analysis of inter correlation matrix. Herewith five variables are includes such as the companies employ retired personals Unemployment in Zambia affect the 
Khazanah Sosial, Vol. 3 No. 3:118-129

The Impact of Youth Unemployment Due To Work Experience Required by Business Houses, Lusaka Zambia

Ananda Kumar et.al

educated and uneducated in the same way, is it correct to say that most of the youths in Zambia are unemployed, Government cares over youth unemployment, The society cares over youth unemployment. The table which shows that most positive correlation scored (+.286) between Is it correct to say that most of the youths in Zambia are unemployed and Unemployment in Zambia affect the educated and uneducated in the same way. The second most positive correlation scored $(+.208)$ between the society cares over youth unemployment and the companies employ retired personals

The most negative correlation scored (-.469) between the society cares over youth unemployment and Government cares over youth unemployment. The second most negative scored (-.412) between Government cares over youth unemployment and Isit correct to say that most of theyouths in Zambia are unemployed.

\section{Discussion}

Many are the times in the life of business that youths are not given the chance or opportunity to express their abilities as regards to the skills they attain while in university (Locke \& Te Lintelo, 2012). They are so inquisitive to showcase what they have learnt and such this experience required is just not favourable for them. Business houses have published articles that have helped to this account to understand the ways and methods to be employed so as to curb this time bomb of youth unemployment in Lusaka and Zambia as a whole. The Government of the republic of Zambia has in many cases talked about reducing the levels of unemployment but the question is whathas been done aboutit.

Unemployment is a serious problem for any growing nation economically more especially Zambian labour market (Chigunta, 2017; Matandare, 2018). It has created a negative effect that affects unemployment as they are jobless and suffering from worse prospects to find new jobs and whose who are employment feel less secured to keep their jobs in future. However, for overall development of economy, government and individual has to take initiative steps increasing the productivity and improving the standard of living. The government and private housesneed structural employment for long term for the youths so thateventually it can swallow the youth unemployment; e.g. the need for infrastructures for schools, primary, secondary and tertiary education (Gough et al., 2016). Furthermore, government requires more infrastructures for health facilities such as clinics in every community, hos pitals in every heavily populated area. Security - where government infrastructures are erected hence the need for government secured infrastructures. Human labour will be mobilized also to secured human life. The governmentis the only entity that has authority, powers to adjust the retirement for any employee in the nation, with the constriction of the economy, there must be a law for an adjustable age package for every employee to sustain them when retired also the new recruit replacing the retired would be comfortable.

young people are in a position of needing support, especially from the environment, both from the church environment and therole of parents besides that the level of job vacancies continuesto emphasize reducing unem ployment. But, the main role is theyouth themselves who choose what kind of life they will lead later. several other factors such as society and government also play an important role in reducing unemployment in Zambia. Research shows a positive correlation about public and government concern for youth unemployment. For this reason, the behavior and will of the youth mustalso be followed so that the government's plans can be implemented properly. 
Khazanah Sosial, Vol. 3 No. 3 : 118-29

The Impact of Youth Unemployment Due To Work Experience Required by Business Houses, Lusaka Zambia

Ananda Kumar et.al

\section{CONCLUSION}

The teacher concluded that important is needed to the youths to deliberate national reconsideration of graduates' education so that the open policy question, the current information gaps and the contemporary stresses are systematically addressed by suitable blend of university industry, profession society and government. More locally flexibility in the design and implementation of policy to address youth unemployed can solve these problems. Job operation participation resulted in gains in employment as earnings in the post program period and in declines in receipt and welfare and unemployment payments. These positive effects persisted at a relatively stable rate for up to four years after youths left the program. More local flexibility in the design and implementation of policy to address youth unemployed can deliver greater efficiencies and better outcomes for young people. Different cities will require different policy to effectively address the core issues they face. Many are also more likely to have a good grasp of the barriers young people face in cities, how to target the most disengaged, what training and employment opportunities are available and which organisation are bestplaced to deal with.

Unless a person fulfils the entire requirement, he or she will not even be considered for the position at hand. Since job description have become so very specific and particular, people are finding it is very tough to even get an interview. At such appoint in time there is little which can do, because companies will not be willing to take on board those who are not exactly perfect for the job. A structural unemployment happens when there is a long-term decline in demand in anindustry leading to fewer jobs or demand for labour falls ways e.g. jobs on a production line being replaced by robot: Motor manufacturing, online banking and online retailing. The government is the only entity that has authority, powers to adjust the retirementfor any employee in the nation, with the constriction of the economy, theremust be a law for an adjustableage package for every employee to sustain them when retired al so the new recruitreplacing the retired would be comfortable.

\section{REFERENCES}

Ajufo, B. I. (2013). Challenges of youth unemployment in Nigeria: Effective career guidance as a panacea. African Research Review, 7(1), 307-321.

Bhorat, H., Cassim, A., Masumbu, G., Naidoo, K., \& Steenkamp, F. (2015). Youth Employment Challenges in Zambia A Statistical Profile, Current Policy Frameworks and Existing Interventions.

Chigunta, F. (2017). Entrepreneurship as a possible solution to youth unemployment in Africa. Laboring and Learning, 10, 433-451.

Chigunta, F., \& Mwanza, V. (2016). Measuring and promoting youth entrepreneurship in Zambia. Young Entrepreneurs in Sub-Saharan Africa, 48.

Gough, K. V, Chigunta, F., \& Langevang, T. (2016). Expanding the scales and domains of (in) security: Youth employment in urban Zambia. Environment and Planning A, 48(2), 348-366.

Guarcello, L., Manacorda, M., Rosati, F., Fares, J., Lyon, S., \& Valdivia, C. (2008). School -to-work transitions: regional overview. Youth in Africa's Labor Market, v(2), 109.

Kabelenga, I. (2017). Zambian elders' experiences and perceptions of the generation gap. Anthropological Researches and Studies, 7, 3-15.

Lim, Y. J. (2013). Strategic communications of the United Nations: Case studies of the department of public information under Secretary-General Kofi Annan, 1997-2006. Ohio University.

Lindsey, I., \& Grattan, A. (2012). An 'international movement'? Decentring sport-for-development within Zambian communities. International Journal of Sport Policy and Politics, 4(1), 91110. 


\section{Khazanah Sosial, Vol. 3 No. 3:118-129}

The Impact of Youth Unemployment Due To Work Experience Required by Business Houses, Lusaka Zambia

Ananda Kumar et.al

Locke, C., \& Te Lintelo, D. J. H. (2012). Young ZAMBIANS 'WAITI NG'FOR opportunities and 'working TOWARDS'LIVING well: lifecourse and aspiration IN youth transitions. Journal of International Development, 24(6), 777-794.

Ma, H.-H. (2006). An alternative method for quantitative synthesis of single-subject researches: Percentage of data points exceeding the median. Behavior Modification, 30(5), 598-617.

Matandare, M. A. (2018). Botswana Unemployment Rate Trends by Gender: Relative Analysis with Upper Middle Income Southern African Countries (2000-2016). Dutch Journal of Finance and Management, 2(2), 4.

Micklewright, J. (1999). Education, inequality and transition. Economics of Transition, 7(2), 343376.

Mohajan, H. K. (2017). Two criteria for good measurements in research: Validity and reliability. Annals of Spiru Haret University. Economic Series, 17(4), 59-82.

Mungule, M. (2016). An exploration of the perceptions of young unemployed graduates in Lusaka, Zambia, of the factors contributing to their unemployment. University of Cape Town.

Sanches, E. R. (2016). Zambia. In Africa Yearbook Volume 12 (pp. 496-504). Brill. 